\title{
Macroeconomics Post-GFC
}

\author{
Iwan Jaya Azis ${ }^{a, *}$ \\ ${ }^{a}$ Cornell University, Ithaca, New York
}

\begin{abstract}
The core model of macroeconomics we teach in colleges and universities uses incredible assumptions to reach absurd conclusions. Among those assumptions are, no financial frictions such as credit rationing, individuals had rational expectations or acted as if they did, and representative agent to represent an aggregation of firm or household sector whose optimizing behaviors are micro-founded. With no financial frictions, the model fails to explain a major event such as the 2008 GFC. Why small shocks can have very large effects (amplification) that last so long (persistence), and why deep downturns can occur repeatedly with powerful spillovers and contagion effects? Constructed for analyzing only small fluctuations, the current core model is likely to provide little guidance as to what should be done in response. In this paper, I argue that the key problem with the current macroeconomics is the superficiality of its treatment towards financial sector. It is shown that financial frictions played a significant role in capital flows fluctuations, external shocks created channels of spillover and contagion across countries and across asset classes, capital flows with the presence of financial frictions made monetary policy more challenging, and they could be detrimental to financial stability and the distribution of income. Corrections and adjustments to existing core macroeconomic model should be based on empirical evidence and how the economy works, not on the esthetic riddles of established paradigm.
\end{abstract}

Keywords: core model; financial frictions; rational expectations; microfoundations; contagion; monetary policy; inequality

JEL Classification: A23; A31; B22; B41; E00; E12; E61

\footnotetext{
*Corresponding Author: Cornell University, New York. E-mail: ija1@cornell.edu.
} 


\section{Introduction}

Who would have thought that February 17, 2008 was the day the global economy displayed an early signal of trouble when the British government nationalized Northern Rock, a U.K. Bank founded in 1850. The financial house of card crumbled since then. It started with JP Morgan rescuing Bear Stearns by buying the 85-year old bank, followed by another extraordinary event on September that year: the US government bailed out Fannie Mae and Freddie Mac, the two huge firms that guaranteed thousands of sub-prime mortgages. Then the most-watched event happened: Lehman Brothers collapsed! And not rescued! This has become the poster child of the 2008 global financial crisis (GFC).

Many economists were caught off guard by the cascading crisis following those episodes. Even prominent macroeconomists were wrongfooted by the event. Standard macroeconomic model we teach in colleges and universities describes how an economy can go off the equilibrium path but any deviations from the path could and would be corrected by inherent mechanisms contained in the model. The nature and speed of that adjustment can be influenced by macroeconomic policy.

But what happened with the GFC proved that the model and the policy failed a reality check. The core model was unable to explain why small shocks could produce very large effects and lasted so long (Azis, 2010).

While making prediction is notoriously difficult, the test of any science is prediction. One should be highly skeptical of a model that fails to predict a major macro-event, and must not rely on it for policy guidance. "If they were unable to foresee something so important to people's wellbeing, what good are they?" quipped Nobel laureate Robert Shiller (2015).

What is wrong with macroeconomics? Is macroeconomics dead? If so, who killed it? If not, shouldn't macro modelers feel embarrassed? Some critics argued that the economic crisis is equivalent with the crisis of economics. All these may sound too provocative, but it is a factual truth that macroeconomics has suffered from a serious lack of robustness. One of the reasons is arguably the focus on models with a well-behaved steady state and on second moments of macroeconomic variables rather than on extreme tail events.

A less provocative question I prefer is: what flaws the current core model suffers from that deserve corrections? ${ }^{1}$ With that question, my main intention in this paper is to argue that we need to incorporate realities of finance into macroeconomics core model. I use the following four examples of post-GFC events associated with capital flows to show that interconnections between financial

\footnotetext{
${ }^{1}$ The "Rebuilding Macroeconomic Theory Project" set up by the Oxford Review of Economic Policy was inspired by the same spirit. Since its inception, several seminars and workshops have been conducted to address some of the issues raised by the Project. The "Advances in Macro-Economic Dynamics: A Workshop on Theories, Models, and Methods" at Cornell University in June 24th-June 26th, 2019 was one of them. Some of the issues I raised in this paper were based on my presentation in that workshop.
} 
market and macroeconomic variables are not only indispensable but also far more complex than what the existing core model suggests.

1. Financial frictions: Spread as a measure of financial frictions explains the fluctuations in capital flows and hence aggregate output.

2. Financial contagion and spillover: In an open economy, any external shocks could easily spillover to domestic financial market, across countries and asset classes.

3. Monetary Policy: During volatile capital flows, interconnections between banks and capital market makes monetary policy more challenging.

4. Income inequality: Some components of capital flows can be detrimental to financial stability and welfare (e.g., income inequality), which, in turn, could hit back aggregate output. Policy measure to counter those components is therefore necessary.

Before discussing each of those issues, I begin with some background to establish the rationale for raising them. And to set the stage, I also discuss the evolution and paradigm shifts in macroeconomics thinking.

\subsection{Background: Evolution of Macroeconomics}

The 2008 event marked a turning point in macroeconomics thinking. The current core macroeconomic model failed to predict its occurrence and evolution, and inconsistent about the sources of disturbances. It was also unable to explain why small shocks can have very large effects that lasted so long. In particular, the model failed to account for the critical roles of financial sector and institutions in the economy as it does not consider financial sector (and banks) important. Economic cycles, according to the model, are driven by producers and consumers of goods and services.

Thus, students of macroeconomics would not learn anything about finance and banking, and their interactions with-and effects on-real sector, let alone contemplate that troubles in finance could have amplified effects through a process of contagion. It is very difficult to explain the GFC by using the current core model, and is almost impossible to understand the rationale or evaluate the effectiveness of the policy response.

The negative interest rate policy (NIRP) is a case in point, where central banks are encouraging savers to spend their money or invest in something riskier than bank deposits and money market funds. The driving force of NIRP was the desire to stimulate economic growth and the fear that anemic expansion could lead to deflation, creating a downward spiral of more negative growth and more deflation (deflation spiral) similar to that occurred during the 1930s Great Depression. ${ }^{2}$

\footnotetext{
${ }^{2}$ Negative interest rates policy was first deployed by Sweden's central bank in July 2009 when the bank cut its overnight deposit rate to -0.25 percent. But they became a major phenomenon since 2014 when the European Central Bank (ECB) decided to pay commercial banks a negative rate on the deposits they held at the ECB. The Bank of Japan (BOJ) followed suit. At the time of writing, 7 major
} 
Under NIRP, commercial banks must pay to keep their money in central banks, rather than collecting interest on it. That means they should have an incentive to lend their money at low cost to borrowers. While that should encourage people to borrow more, spend more and save less, hence stimulate the economy, retail banks have been reluctant to pass on NIR to customers, choosing instead to leave households earning at least zero percent on their deposits. This means banks' net interest margins have shrunk, hurting bank profitability, potentially curbing lending supply and thus hampering economic activity. Unchanged interest earned by household and firms also translates into no stimulation for consumption or investment. There is no way the current core model can explain this phenomenon. Why? Because no textbooks on macroeconomics before 2008 covers a topic on negative interest rates.

Related to NIRP, the 'quantitative easing' (QE) is another unprecedented policy not analyzed in any standard macroeconomics textbooks. Consisting of central bank's purchases of large-scale assets, but uncommonly include private asset-backed securities, the QE policy was taken against the backdrop of global recession where short-term nominal interest rates were already low, zero, or negative. The intended goal of injecting a significant amount of liquidity was to recover plunging asset prices so that businesses and financial sector could resume their normal operations to revive the economy and avoided a deflation spiral.

Some of the impacts of the policy, however, were unintended. Asset prices shifted the wealth distribution because the composition and leverage of household portfolios differed along the wealth distribution: i.e., rich households predominantly owned equity, middle-class portfolios were dominated by housing, while the poor hardly owned assets. Thus, asset price increase and housing booms following the QE policy led to substantial wealth gains for the rich, worsening the wealth and income distribution. Not to mention the fact that most of the injected liquidity stayed in the financial sector, including abroad in the form of capital flows largely going to emerging market economies (EME). The sky-high housing prices have created other problems, including shortages of affordable housing options, strains on household budgets, reduced mobility, and growing wealth inequality. Thus, the impact of QE policy has not been confined to macro indicators.

But it was the series of episode leading to the NIR and the QE that brought fundamental changes in macroeconomics thinking. The GFC itself was only a culminating event. It was preceded by other episodes: the 'great inflation' of the 1970s, the 'great moderation' since 1980s, and the 'global imbalances' during the years prior to the GFC. Changes in macroeconomic model took place during those events, some reflect a progressive evolution, others indicate a real paradigm

central banks have pushed their main policy rate to negative territory: Danmarks Nationalbank, Bank of Japan, Magyar Nemzeti Bank, Bulgarian National Bank, European Central Bank, and Swiss NationalBank \& Sveriges Riksbank. 
shift.

The New Keynesian approach, emerged as a response to the 'great inflation,' is an example of evolutionary change. Another example is the Real Business Cycle (RBC) theory developed by Edward C. Prescott (1986) and other freshwater economists, which attributes economic cycles to technology shocks rather than aggregate demand fluctuations. The theory is often associated with the New Classical thinking.

Among the paradigm shifts in macroeconomics, there are two types: full and partial. The Keynesian revolution is a clear example of a full paradigm shift. It drastically departed from the Marshallian economics. Before Keynes, macroeconomics was analyzed by using Alfred Marshall's partial equilibrium method. The problem of unemployment, for example, is caused by actual wages above market level such that the supply of labor exceeds the demand. Hence, unemployment can be reduced only by a wage cut; no role of income or output in the labor market (assumed exogenous). A general equilibrium framework was nowhere found in the analysis.

The 1930 Great Depression discredited such a view. As we know now, if aggregate demand fails to rise and producers cannot sell their products, a wage cut alone will not raise the demand for labor.

On the financial side, Marshallian views consider interest rates as the price of savings and investment. When interest rates are above equilibrium (the level where savings equal investment), people save, and firms pay more to borrow. As a result, supply of savings will rise above demand for investment. The only way to equate savings and investment is by reducing the interest rates. Again, the role of income and output, which is standard in a general equilibrium framework, was nowhere found in the analysis.

Keynes changed all that by introducing money market and argued that interest rates are determined by liquidity preference in money market. Hence, interest rates perform as an equilibrating factor in money supply and money demand, not in savings and investment. Formalized and further developed by Hicks (1937), the concept eventually led to the famous two-equation IS-LM model by treating prices exogenous. Reversing the role, i.e., making wages exogenous and prices endogenous, Samuelson (1951) made the working of Keynes' general equilibrium framework easier to understand. This was later known as the 'neoclassical synthesis of general equilibrium.'

The Keynesian macroeconomics was well received and widely used to guide macroeconomic policymaking. The satisfactory performance from it was labeled the 'Golden Age.' Until something happened in the 1970s: another paradigm shift in macroeconomics, i.e., the use of micro foundations for macroeconomics. This new approach was considered a 'revolution' in macroeconomic modeling. The kind of micro foundations used, however, turned out to be very critical. When strict assumptions on the behavior of agents with respect to expectations are imposed, the approach becomes suspect, qualifying it as only a partial shift of paradigm. 
A precursor to the approach was the Lucas critique which fundamentally changed the way macroeconomic models are constructed, especially when the models are used to evaluate the effects of changes in policy. Instead of relying on agents' past behavior to predict the behavior after a policy change (assuming a stable structure), it is argued that the model should allow agents to form expectations about the future and change them in response to that new policy, providing the expectation are consistent with model prediction. This is the essence of rational expectation (ratex).

One of the important implications of ratex is: Keynesian macroeconomic policy is ineffective and unnecessary. For several years, ratex was seen potential to become a real paradigm shift as it successfully changed the way academic macroeconomics was done. It also posed an existential threat to Keynesian macroeconomics. ${ }^{3}$ However, the dependence on agents' optimizing behavior and its insistence that expectations are rational have tainted ratex credibility. Contrary to its premise and prediction, macroeconomic policy remains effective and necessary.

Given the evolution of concepts, ideas, and models described above, it is logical for macroeconomists to integrate relevant components from different paradigms. After years of contentious debates on how and what to integrate, a new 'baby' was born: Dynamic Stochastic General Equilibrium (DSGE) model, which later became 'benchmark' in core macroeconomic model.

Designed for an environment of competitive economy albeit with some distortions (e.g., nominal rigidities, information problems, monopoly power), and to be estimated as a system, not equation per equation like in previous models, DSGE is best seen as large-scale version of the New Keynesian model. It puts the emphasis on nominal rigidities and role of aggregate demand. ${ }^{4}$ Unlike the IS-LM model, DSGE model is microfounded and uses optimizing behavior of representative agents (consumers, firms, and financial intermediaries). In the model, asset prices are largely determined by inter-temporal budget constraints, and the growth and capital accumulation are specified based on the Solow-Swan-Ramsey growth model but with forward-looking investors (what is saved is not always used for investment). Inflation and output gap are derived from the inequality of aggregate demand and aggregate supply with some nominal rigidities present. Monetary policy that comes out from the model is based on Taylor rule macro, from which output and inflation are simultaneously determined, while fiscal pol-

\footnotetext{
${ }^{3}$ Efforts were made to counter criticisms against the Keynesian model, among others by incorporating a Phillips curve to allow for adaptive inflation expectations. To the extent higher inflation expectations driven by rising inflation could create a wage-price spiral (Friedman, 1968), the model needs to incorporate an expectation-augmented Phillips curve. Indeed, adding a Phillips curve to the IS-LM model have changed the way macroeconomists thought about policy, and discredited Friedman's idea of non-interventionist macroeconomic policy (a key feature of monetarism). Other attempts include creating an explicit nominal anchor and endogenizing the supply side of the model.

${ }^{4}$ The RBC model cited earlier is seen as the 'early' version of DSGE with no distortions and where the focus was on the effects of productivity shocks.
} 
icy to stabilize the aggregate demand is linked to debt and the interest payment, hence taxes too (e.g., bigger deficit raises debt and requires higher taxes to pay for the debt interest).

While DSGE model has been widely used, especially by central banks around the world, by now it is acknowledged that it miserably failed to explain an event like the GFC, why it happened, what policy to take to avert it, and how to mitigate the impacts. Being dynamic (lots of things are changing over time), stochastic (as in random shocks to the economy), and general equilibrium (producing a result in which the broad economy is in equilibrium), the model is quite well placed. But there are too many restrictions imposed that do not represent the most fitting restrictions to capture empirical evidence. More seriously, DSGE model excludes everything relevant to the pursuit of financial stability. ${ }^{5}$ Unless we are fully convinced that a financial crisis will not happen again, it is hard to think an alternative other than replacing it with another model (essentially to discard DSGE). The question is, what kind of new model?

Opinion varies on this. One contentious point of disagreement is whether we should focus on improving the basic foundational model or rework and correct the micro foundations of the model. Stiglitz (2014) argued that attempts to reconcile macro and microeconomics by making the former adopt the standard competitive micro-models are flawed as they failed to treat more explicitly the important ingredients of the theories of imperfect and asymmetric information, game theory, and behavioral economics. According to him, it would have been more appropriate to try to gather from macroeconomics insights about what was wrong with the traditional microeconomic models and reform them accordingly. In "Do DSGE Models Have a Future?," Oliver Blanchard (2016) expressed a rather different idea: ".....the current DSGE models are seriously flawed, but they are eminently improvable and central to the future of macroeconomics. To improve, however, they have to become less insular, by drawing on a much broader body of economic research. They also have to become less imperialistic and accept to share the scene with other types of general equilibrium models."

\subsection{Macroeconomics and Financial Sector: Post-GFC Events}

In 'Rebuilding Macroeconomic Theory Project,' Vines and Wills (2018) asked: "Is the benchmark DSGE model fit for purpose." The answer from most participants was a resounding "no," and most of them agreed that the revised core macroeconomic model should: (a) incorporate financial frictions, (b) relax the rational expectations assumption, (c) incorporate heterogenous agents, and (d) adopt better and more persuasive micro foundations.

Discussing all those four is beyond the scope of this paper. Instead, to support the first items I discuss some relevant post-GFC events associated with capital

\footnotetext{
${ }^{5}$ Charles Goodhart of the LSE, who was once a member of the Bank of England's Monetary Policy Committee, once said about the DSGE model: "It excludes everything I am interested in."
} 
flows. It is my contention that the role of financial sector is too important for macroeconomics to undermine.

\subsubsection{Financial Frictions}

In order to differentiate financial risk shocks from standard macroeconomic shocks, incorporating financial sector and frictions in macroeconomic model is necessary. Interactions between financial volatility and financial frictions have been well investigated. The following references contain useful discussions on theories related to financial frictions: Bernanke-Gertler (1989) on the role of information frictions and financial accelerator; Bernanke et al. (1996) and KiyotakiMoore (1997) on asset value and the role of collateral; Gertler and Kiyotaki (2010) on the principal-agent problem; and Stiglitz and Greenwald (2004) on agency cost and borrowers' balance sheet.

From macroeconomic perspective, understanding the deep mechanisms underlying financial frictions is important because the role of finance goes beyond just providing financial intermediation. It could affect agents' expectations and behavior, hence aggregate spending and capital flows. More fundamentally, financial variables and institutions should not play only as an exogenous role because they are affected by the dynamics of real sector and fluctuations of other nonfinancial macro variables. Thus, interactions among financial and non-financial variables should be clearly specified in the revised core model. Obviously, this is a daunting task, yet inevitable if true answers are looked for regarding what the sources of disturbances are, as well as why small shocks can have very large effects (amplification) that are persistent and lasting so long.

Volatility increases the risk and monitoring costs, and in turn it will widen the spread. The spread between returns earned by firms and returns earned by savers is often used as a measure of financial friction. ${ }^{6}$ Its size can be influenced by agency frictions within firms in relation to lenders, within financial intermediaries, and between financial institutions and investors.

In the case of capital flows, in addition to interest rate differential, it is generally accepted that economic growth and commodity prices have a very important role in affecting capital flows to emerging market economies (EMEs). A study by the U.S. Federal Reserves confirms this: between 2010 and 2015 those two variables together explain over two-thirds of the 3.9 percent of GDP slowdown in capital flows to EMEs (excluding China). However, interest rate differential turns out not a good predictor (Table 1). Instead, what is also significant is the global spread of emerging market bond index (EMBI).

Seen as a proxy of financial friction, the greater the friction in the bond market the more discouraged investors will be, confirming the vital role of financial friction in influencing capital flows, one of the most prominent macroeconomic

\footnotetext{
${ }^{6}$ For example, the spread between low quality corporate bonds and government bonds of the same maturity, or the spread between high quality bonds and government bonds.
} 
Table 1: Dependent Variable: Net Private Flows to EME ex-China (\% GDP)

\begin{tabular}{|c|c|c|}
\hline & Coefficient & Robust Standard Errors \\
\hline \multicolumn{3}{|l|}{ Growth Prospects } \\
\hline Growth differential & $0.182 *$ & $(0.084)$ \\
\hline Change in commodity prices & $0.069 \cdots$ & $(0.023)$ \\
\hline \multicolumn{3}{|l|}{ Monetary Factors } \\
\hline Change in (shadow) FFR & -0.554 & $(0.330)$ \\
\hline Interest rate differential & 0.105 & $(0.076)$ \\
\hline \multicolumn{3}{|l|}{ Risk Factors } \\
\hline $\mathrm{VIX}$ & -0.019 & $(0.029)$ \\
\hline EMBI Global spread & $-0.492 *$ & $(0.212)$ \\
\hline EMBI Global spread squared & 0.004 & $(0.003)$ \\
\hline \multicolumn{3}{|l|}{ Additional Controls: } \\
\hline Lagged dependent variable & $0.252 \cdots$ & $(0.049)$ \\
\hline Country fixed effects & Yes & \\
\hline Observations & 1,276 & \\
\hline R-squared & 0.386 & \\
\hline
\end{tabular}

Source: Clark et al. (2016)

Note: Statistically significant at ${ }^{*} 10$ percent, ${ }^{* * 5}$ percent, and ${ }^{* *} 1$ percent Standard errors clustered at country level.

variables to watch after the GFC.

\subsubsection{Financial Contagion and Spillover}

"Money has wings" and "money has no home." These are expressions to suggest that money could easily drift from one hand to another and one country to another. Any effects-good and bad-of it could significantly alter the way macroeconomic variables interact with each other.

When the post-GFC ultra-easy monetary policy in advanced economies drove capital out to flow into emerging markets, EME's domestic financial markets were affected, changing the landscape of domestic liquidity. Any shocks and volatility in source countries could translate into shocks and volatility in destination countries. How significant were those contagion? In Asia, they were very significant.

We did a study on this and revealed that the threat of financial contagion from external shocks-more particularly shocks in bonds market in the U.S. during the Lehman collapse and in Europe during the EU crisis-to Asian financial markets was real, far from trivial (Azis et al., 2013). Using the GARCH model with BEKK specifications, we found that although the region's local bond market volatilities 
were determined more by their own shocks and volatilities, the spillovers in terms of direct shock and volatility were significant. ${ }^{7}$ What is more startling, as shown in Figures 1a and 1b, the external shocks also diffused indirect spillovers, both the shock spillovers and volatility spillovers, across asset classes within domestic markets as well as across countries.

A study by the ECB looking at the potential impact of QE on EMEs found similar results: the volatility experienced by EMEs was caused by the expanding balance sheet of the ECB and the U.S. Fed. The study also indicated that EME bond markets are most susceptible to positive volatility spillovers from both the Fed and the ECB in terms of magnitude of the effect." ${ }^{\prime 8}$

In existing core macroeconomic model, external events like this would normally be analyzed using either the 'uncovered interest parity' (UIP) in which interest rates are the main instrument to manage capital flows, or the MundellFleming trilemma model of an open economy where governments have to manage their desire to maintain domestic financial stability, pursue autonomous financial policies, and integrate domestic financial markets with global financial markets (the 'impossible trinity'). ${ }^{9}$

Obviously, these models are far from adequate to deal with highly volatile and massive capital flows. Interest rate is not the right policy instrument as it is too blunt a tool, affecting the whole economy rather than resolving the problem at hand. Succumbing to the trilemma concept within the current core model could either lead to a disastrous outcome or turn ineffective. More seriously, those standard models undermine the seriousness of contagion effects. In Stiglitz (2014) words: "They didn't even contemplate that the effects could have been amplified in a process of contagion." Based on a revised core model, in which macroprudential tools should be part of, policy monitoring and coordination

\footnotetext{
${ }^{7} \mathrm{GARCH}$ or 'generalized autoregressive conditional heteroskedastic' model is a tool of analysis for time series data particularly in financial applications. Employing it is especially useful when the goal is to forecast volatility. BEKK or Baba-Engle-Kraft-Kroner is MGARCH (multivariate GARCH) model; it is a restricted version of the 'vector error correction' (VEC) model defined in Engle and Kroner (1995). The model has the attractive property that the conditional variance-covariance matrix is positive definite by construction; see Azis et al. (2013).

${ }^{8}$ In page 20 of the report, it is further remarked: "The policy implications of our paper are two-fold: First, EMEs need to pay particular attention to changes in the balance sheets of the FED and ECB given the extent to which there is an effect on domestic financial and real economy volatility. This is particularly the case with respect to EME bond markets, which have been subject to the most notable volatility spillovers in terms of magnitude. The most affected countries in general have been those with a more open capital account and greater financial linkages with the U.S. and euro area economies."

${ }^{9}$ To explain the trilemma, Krugman et al. (2015) developed a model by examining equilibrium in the goods market and equilibrium in the asset market, both as functions of the exchange rate and income. Feenstra and Taylor (2014) remarked that the monetary trilemma "is one of the most important ideas in international macroeconomics." The other important ideas are: John Maynard Keynes idea on multipliers associated with fiscal policy, the Nash equilibrium in game theory, the Stolper-Samuelson international trade theorem on tariffs and wages, Hyman Minski's financial instability model, and George Akerlof's analysis of asymmetric information in markets.
} 

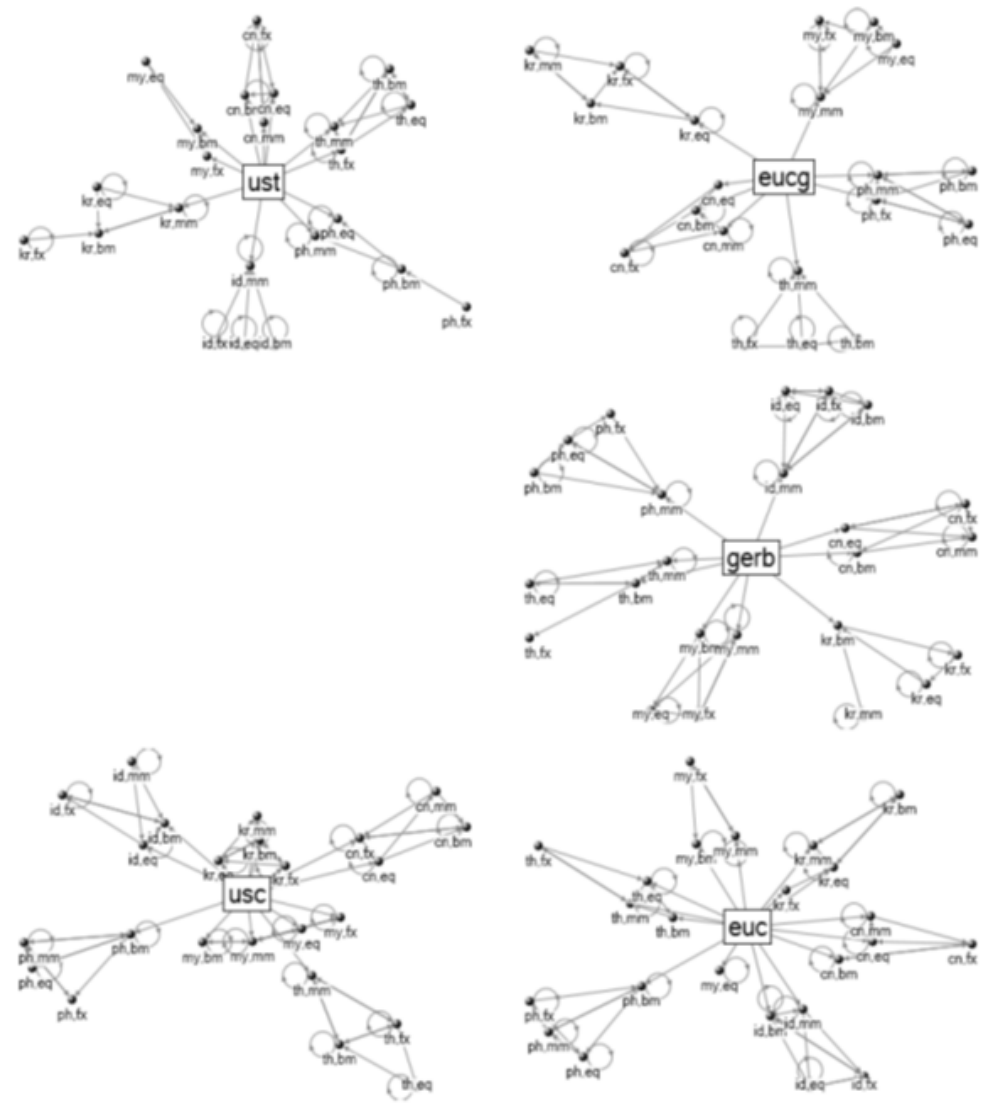

Figure 1a: Shock Spillover \& Persistence: Lehman Collapse (Left) \& EU Debt Crisis (Right)

Source: Azis et al. (2013)

Notes: The drawn lines are the statistically significant spillovers. The shock origins are: ust=US Treasury; usc=US high yield corporate bonds; eucg=EU composite government bond; euc= European corporate bond. The impacted countries are: $\mathrm{pph}=$ Philippines; $\mathrm{my}=$ Malaysia; id=Indonesia; $\mathrm{kr}=$ Korea; $\mathrm{cn}=\mathrm{China} ; \mathrm{jp}=$ Japan. The impacted markets are $\mathrm{mm}=$ money market; $\mathrm{bm}=$ bonds market; eq=equity market; $\mathrm{f} x=$ currency market.

beyond national jurisdictions may thus be one of the recommended solutions.

\subsubsection{Monetary Policy: More Challenging}

Massive amounts of capital flows post-GFC changed the global liquidity dramatically. Faced with such a change, agents' behaviors changed as well (see Azis and Shin, 2015). This has important implications on the way standard macroeconomic mechanisms work. More specifically, it makes monetary policy more challenging. 

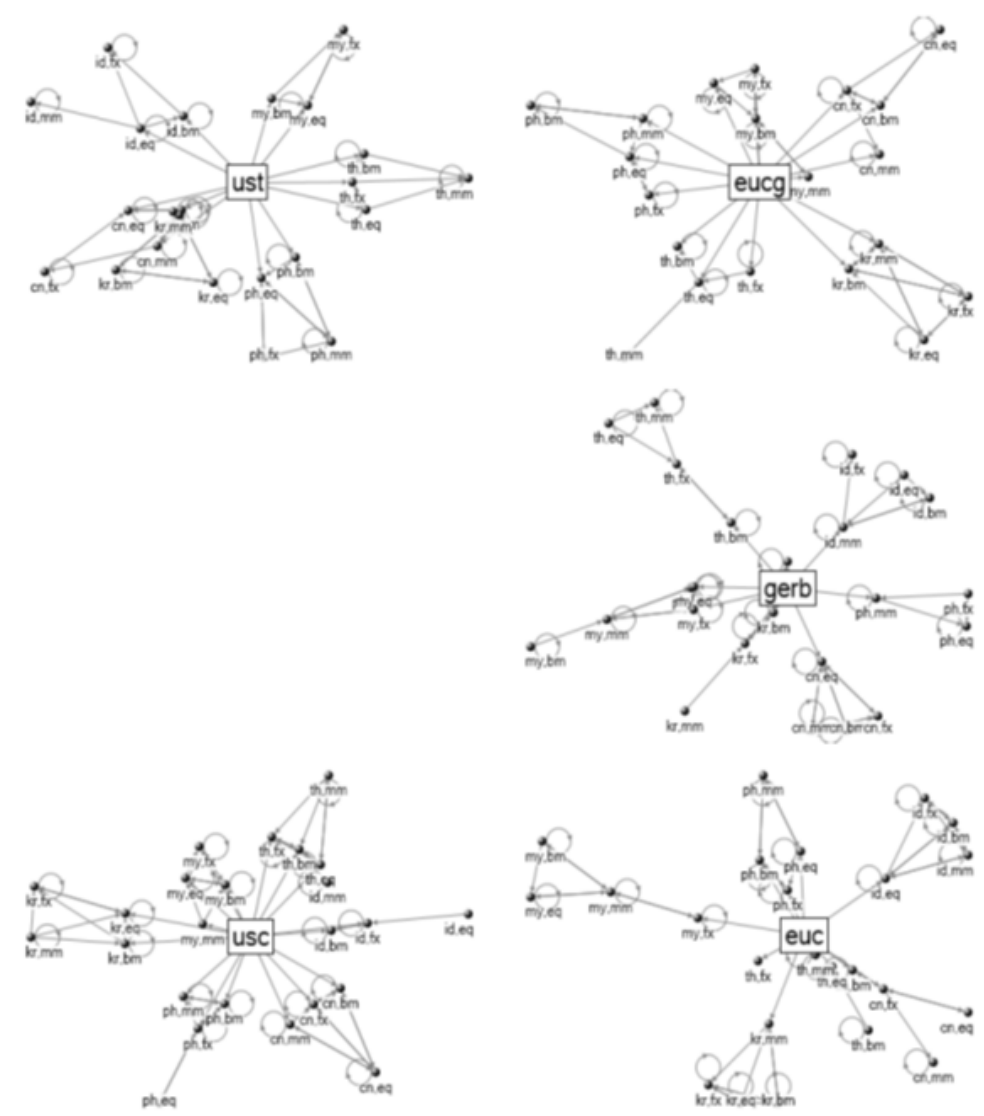

Figure 1b: Volatility Spillover \& Persistence: Lehman Collapse (Left) \& EU Debt Crisis (Right)

Source: Azis et al. (2013)

Notes: same as in Figure 1a.

Increased asset prices and inflation prompted by large capital inflows tend to lure agents to opt for holding securities and other risky assets. In such circumstances, monetary authority tries to curb inflation by raising the interest rates. The resulting fall of prices of securities could worsen the net worth of firms holding those securities, raising the probability of firms' bankruptcy. If banks are the ones who hold a large amount of government bond, as is the case in most emerging markets including Indonesia, increased interest rates could drive down the mark-to-market prices, deteriorating banks' balance sheet. ${ }^{10}$ The

\footnotetext{
${ }^{10}$ On the other hand, falling bond prices could help lower the debt burden of bond issuers (govern-
} 
impact would be more severe compared to the case if this happens in non-bank or non-financial firms, because troubles in banks, even if occuring in just a few numbers of them, will have systemic risks that could threaten the country's entire financial market and macro aggregates. It is therefore imperative to incorporate interest rates and banks' financial structure in the core model.

From the theoretical standpoint, the effect of monetary policy can be bigger and more amplified than what the standard macroeconomic model suggests (Stiglitz and Greenwald, 2014). Holding a large portion of government bonds or other securities, banks' decision to lend is no longer simply determined by some constraints like in a standard monetary economics; rather, it is a choice variable. Thus, it is important to incorporate a mechanism explaining how those choices are affected by monetary policy.

In a principal-agent problem, credit and investment cycles are affected by a depressed firm's collateral value due to falling asset prices or worsening firm's balance sheet. This raises the agency costs imposed by asymmetric information between borrowers and lenders. ${ }^{11}$ Thus, in addition to the size of loanable fund (LBL), an alternative credit equation with agency costs would include the networth of borrowers and lenders (banks), as well as the asset composition of lenders (see Azis, 2008):

$$
\begin{aligned}
& \text { CREDIT }_{i} \\
& \quad=s_{i} L B L_{\text {Combank }}\left[\left(\frac{W E A L_{\text {Corp }}}{\left(P_{K} K\right)_{\text {Corp }}}\right) W F_{K}\right]^{\mu 1}\left[\frac{B_{\text {ComBank }}^{\text {recap }}}{A S_{\text {ComBank }}}\right]^{\mu 2}\left[\left(\frac{W E A L_{\text {ComBank }}}{\left(P_{K} K\right)_{\text {ComBank }}}\right) W F_{K}\right]^{\mu 3}
\end{aligned}
$$

where $W F_{K}$ is the unit value of capital used to measure wealth value, $P_{K}$ and $K$ are the price of, and demand for, capital, respectively, $s_{i}$ is positive constant, and $\mu 1, \mu 3>0$, and $\mu 2<0$. The second part of the RHS denotes the proportion of bank's risk-free asset including the recap bonds, and the last part captures the bank's net worth. Thus, a depressed value of net worth leads to a lower amount of credit, so does a high proportion of illiquid asset in lender's total asset. ${ }^{12}$

Using the above model to analyze the Indonesian experience during early 2000s, where repeated decrease of interest rates by Bank Indonesia failed to boost credit, it was revealed that the estimated credits are much closer to the actual data compared to the estimates from using a standard model (Figure 2). More importantly, the sensitivity analysis shows that credits are indeed very sensitive to banks' asset composition, more so than to banks' net worth (Figures 3a and

ment). Yet, if the bond holding by banks or firms exceed bond issuance, as in the case of many EMEs including Indonesia, falling prices due to higher interest rates will deteriorate their balance sheet.

${ }^{11}$ Asymmetric information implies that there is a cost for acquiring information (agency cost) and this cost is sunk (credit market is inherently imperfectly competitive).

${ }^{12}$ The well-known 'credit channel' specifies that credit or bank loan is not only determined by the size of a bank's available funds but also by changes in net worth and external finance premia of both borrowers and lenders (Bernanke et al., 1996; Adrian and Shin, 2009; Stiglitz and Greenwald, 2003; and Stiglitz, 2001). 
3b). At any rate, the importance of banks' financial structure in credit decision is undisputed, and this clearly affects aggregate output and other macro variables. ${ }^{13}$

In some recent macroeconomics textbooks (e.g., Blanchard, 2017), the discussions on banks' bankruptcy have been included, where it is explained that banks' higher leverage implies a higher risk that the value of assets becomes less than the value of liabilities, and this leads to a higher risk of insolvency. Too low a leverage ratio for banks means less profit, too high a leverage ratio means a higher risk of bankruptcy. Yet, the interrelations with macro aggregates are still opaque as the core model being used remains absence of detailed interactions between different financial assets-liabilities, agents' behavior towards financial products, and macro aggregates. ${ }^{14}$

\subsubsection{Inequality and Poverty}

In a traditional thinking, capital inflows are always good for the economy. When they surged into EME capital market following the QE policy, fund managers played as protagonists who prefer quick returns (because of bigger rewards) and are willing to tolerate riskier investment (because of reduced penalty). Banks also enjoyed receiving inflows channeled through their system. In public sector, low cost of borrowing motivated governments to raise debt. Thus, everyone took advantage of cheap money and fast-growing financial sector. Everyone danced with the tune during "party" time. Standard macroeconomic indicators including GDP growth also improved, indicating that the outcome of agents' rational behavior is Pareto optimal and, at least on the surface, looks Pareto efficient too. Yet, as discussed below, it is far from socially optimal.

It is widely known that risks of financial instability are likely to increase with the surge of inflows. This topic has been well-established in economic literatures. For the case of Asia, Azis and Shin (2015) showed the impacts and how the mechanisms work. I therefore do not wish to repeat it here. Instead, I intend to show a less known fact that increased inflows could exacerbate the skewed distribution of wealth and income (the "Piketty-moment") as only a very small portion of the population-mostly urban-rich-owned or had access to the fast-growing financial sector. The economy's capacity to generate employment (employment elasticity) also tends to decline because growing preference towards

\footnotetext{
${ }^{13}$ Note, however, that the RHS of the equation are also sensitive to the macro variables. Thus, a system of interdependence should ideally be incorporated in the revised core model.

${ }^{14}$ Blanchard (2017) discusses the link between firm's bankruptcy and inflation in the context of Phillips relation, and between bank's bankruptcy, leverage and profit. On firm's bankruptcy, it is stated "If inflation turns out higher than expected, real wages may plunge, and workers will suffer a large cut in their living standard. If inflation turns out lower than expected, real wages may go up sharply. Firms may not be able to pay their workers. Some may go bankrupt." On bank's bankruptcy "higher leverage also implies a higher risk that the value of the assets becomes less than the value of its liabilities, which, in turn, implies a higher risk of insolvency......... Thus, the bank must choose a leverage ratio that takes into account both factors. Too low a leverage ratio means less profit. Too high a leverage ratio means too high a risk of bankruptcy."
} 


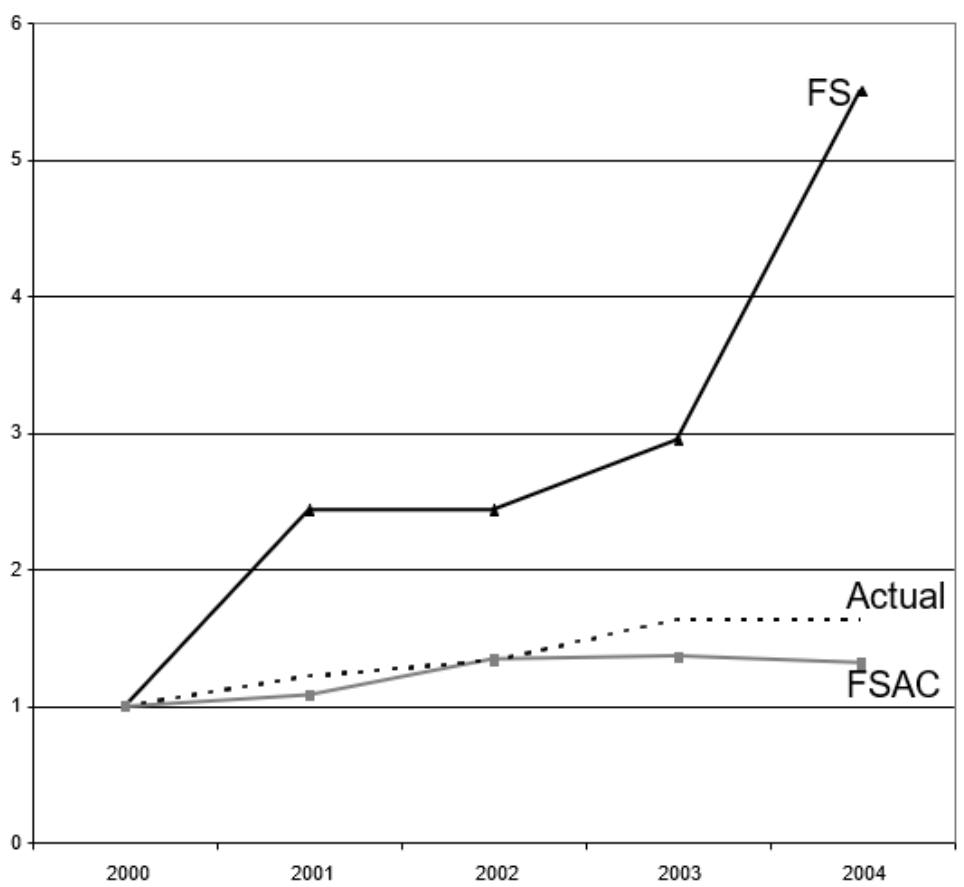

Figure 2: Trend of Credits: Actual, With, and Without Agency Cost Source: results of the author's model simulation

Notes: $y$-axis denotes the index $(2000=1)$. FS shows credit estimates based on a standard financial sector model without agency costs. FSAC shows the credit estimates taking account the agency costs.

financial assets implies a far lower investment in factories, machinery, and other job-creating activities (Azis \& Shin, 2015; see also earlier discussions on the impact of QE policy in the U.S. and Europe).

To the extent income inequality has been growing everywhere, the revised core macroeconomic model should include mechanisms involving household incomes of different groups. For developing countries struggling to lift the living conditions of poor households, it is also important to include variables associated with poverty measure.

Recent studies found that poverty-inequality nexus significantly affect output growth and other aggregate variables. Unlike the classical view showing inequality has a positive effect on growth, the modern view suggests the opposite: a negative effect of inequality on growth (McKay and Thorbecke, 2015). The mechanisms work through greater rent-seeking and insecure property right, social instability and greater uncertainty, and more distortion due to a great number of poor median voters, all of which could have a detrimental effect on growth (Figure 4). 


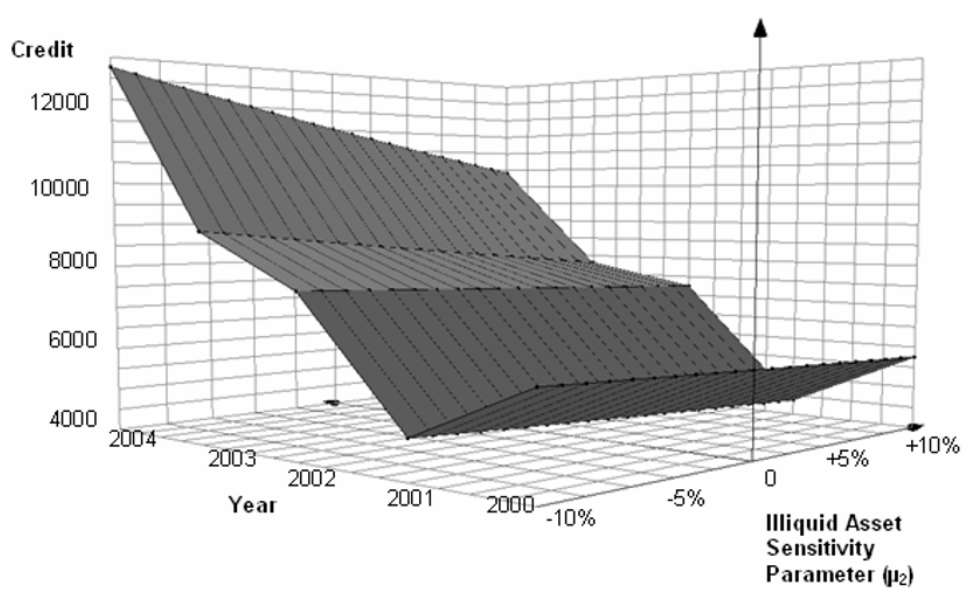

Figure 3a: Sensitivity Analysis: Changes in Illiquid Assets, $\mu 2$ Source: results of model simulation; see Azis (2008)

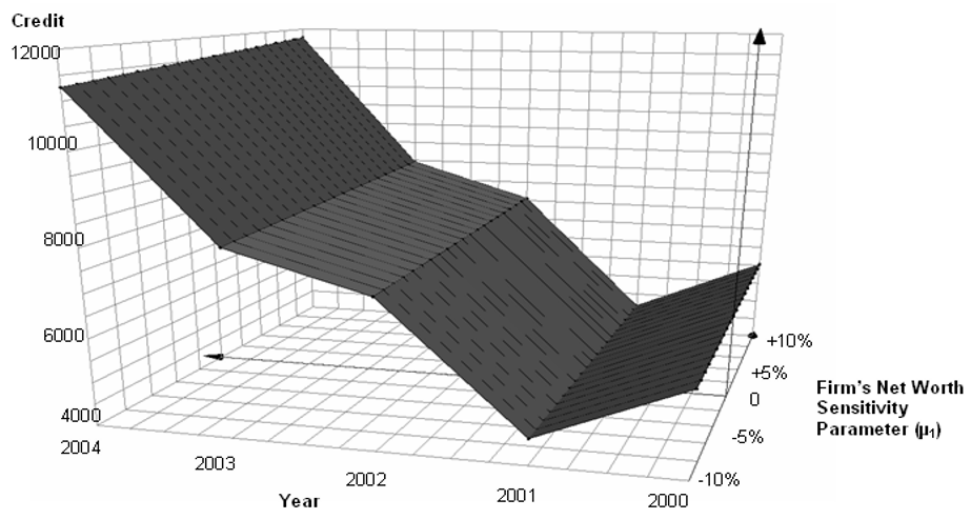

Figure 3b: Results of Sensitivity Analysis for Credits with Agency Cost: (For Changes in Bank's Net-Worth, $\mu 1$ )

Source: results of model simulation; see Azis (2008)

If welfare including inequality and poverty indicators are of interest, the following steps should be taken. First, split the portfolio inflows into the part that goes to productive activities (e.g., infrastructure through government bond; Azis, 2014) and those staying within financial market (e.g., search for yield); second, break-down the income flows into incomes related to financial assets and those coming from factor incomes and transfers. Lastly, we need to incorporate a mechanism explaining how different types of inflows end up in different institutions. 


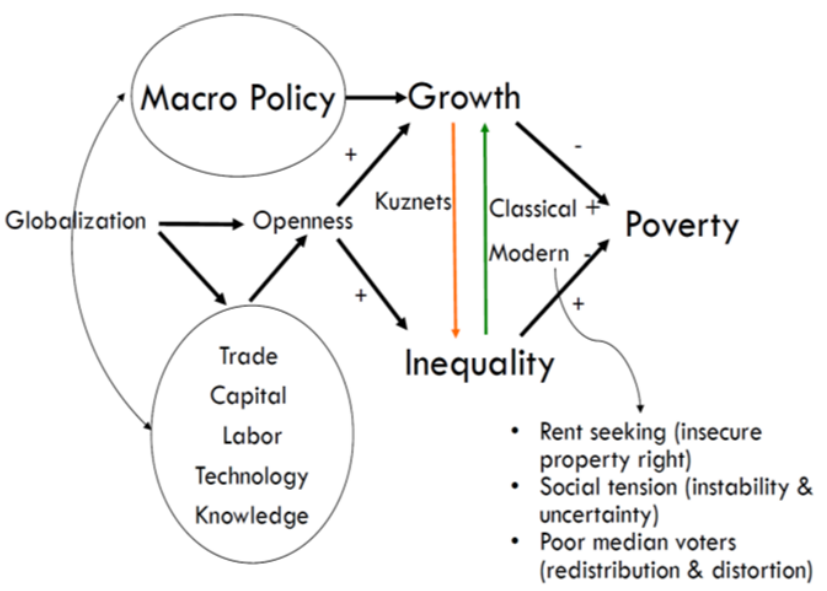

Figure 4: Macro Policy, Growth, and Inequality: Classical Versus Modern Views Source: modified from McKay and Thorbecke (2015) and Bourguignon (2004)

In Figure 5, the component on the right-hand side of the diagram captures the mechanisms and types of inflows, while on the left side shows how total incomes are received by different institutions. Notice that some of the inflows end up in fixed assets (productive activities) and others in financial assets (search for yield).

The fixed assets are linked to aggregate output and other macro variables via aggregate investment, and factor income generated from such activities would be part of total incomes (left side of the diagram). The other part consists of transfers (e.g., subsidy to the poor), changes in value of financial assets (valuation effect), and returns on financial assets (yields on securities, stock returns, etc). Hence, the actual incomes received by urban-rich households owning financial assets can be well above incomes accrued to those who do not have financial assets. During the post-GFC period, when capital inflows were massive and asset prices increased, asset and income inequality got worse through such a mechanism. ${ }^{15}$ And according to modern views (see again Figure 4), this put a downward pressure on growth, and hence aggregate variables.

Given such detrimental effects, the structure of a revised core model should contain mechanisms whereby the arrow emanating from "Capital Flows" (CFLOW) to "Financial Liabilities" (FINLIABS) on the bottom right of the diagram are broken down and specified in greater details (i.e., through a sub model) such that the

\footnotetext{
${ }^{15}$ It would be highly relevant for many developing countries to have a core macro model with target goals that includes poverty reduction. From aggregate price level (PINDEX), one can make a specific formulation to extract the price of basic needs, hence the poverty line (PL). Combined with the extracted information on incomes of different households, particularly of the poor households, this would allow us to estimate the poverty rate endogenously.
} 


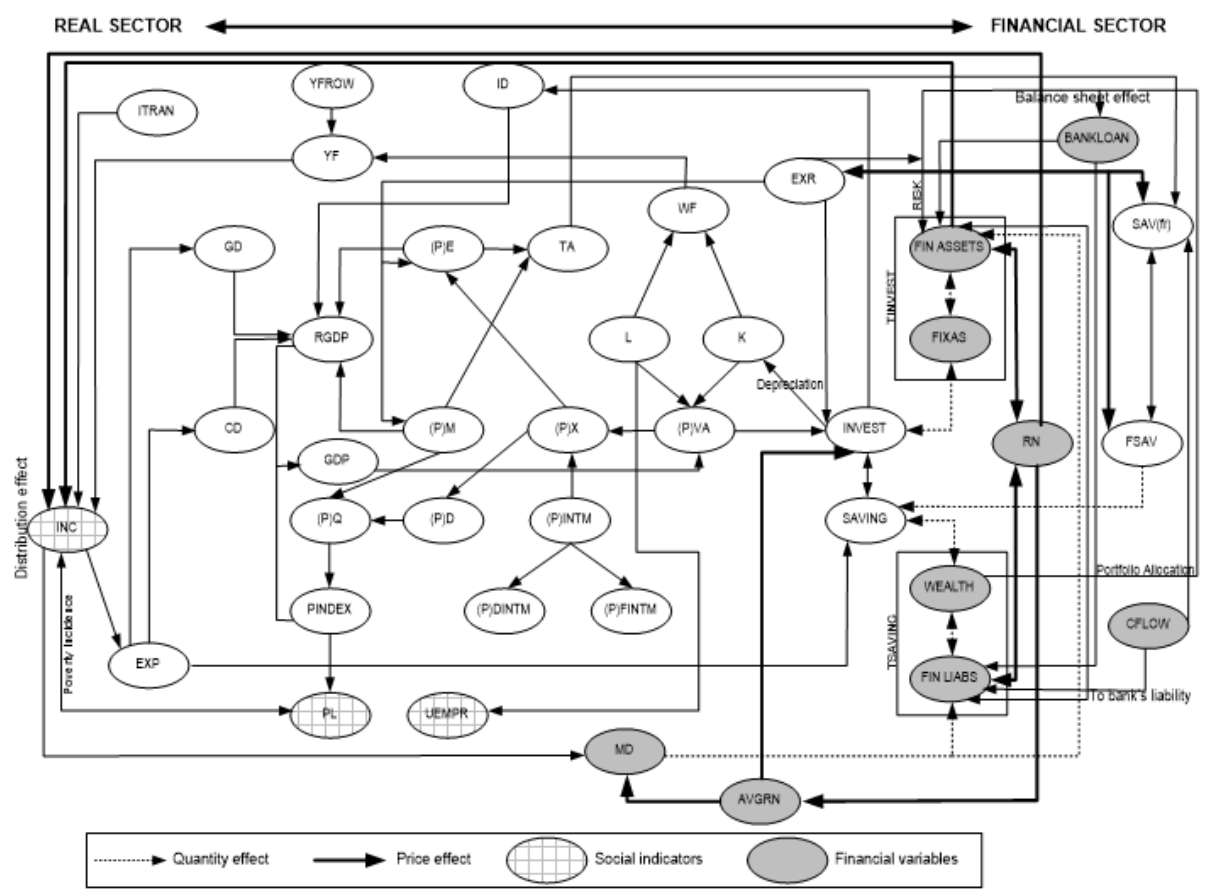

Figure 5: Diagram of Macroeconomic Models Linking Capital Flows and Household and Institutions Incomes

Source: Azis and Shin (2015)

Notes: $\mathrm{P}=$ prices; $\mathrm{X}=$ output production; $\mathrm{D}=$ domestic sales; $\mathrm{E}=$ exports; $\mathrm{M}=$ imports; $\mathrm{Q}=$ total supply; VA = value added; INTM = intermediate inputs; FINTM = imported intermediate inputs; DINTM = domestic intermediate inputs (DINTM); $\mathrm{L}=$ labor; $\mathrm{K}=$ capital; WF = returns on primary inputs; YF = factor incomes; YFROW = factor incomes from abroad; INC = total income; ITRAN = transfers between institutions; $\mathrm{GD}=$ government expenditure; $\mathrm{CD}=$ real consumption; $\mathrm{EXP}=$ agents' expenditure; YCON = disposable income; FSAV = foreign saving; FIN ASSETS = financial assets; RN = returns on assets; CFLOW = capital flows; BANKLOAN = loans; FIN LIABS = financial liabilities; FIXAS = fixed assets; INVEST = investment by destination; ID = investment by source; RGDP = real gross domestic product; $\mathrm{SAV}(\mathrm{fr})=$ foreign savings; $\mathrm{EXR}=$ exchange rate; $\mathrm{TA}=$ trade account;

SAVING = saving; WEALTH = total wealth; $\mathrm{MD}=$ money demand; AVGRN = average returns; $\mathrm{PL}=$ poverty line; UEMPR = unemployment rate; PINDEX = price index (aggregate price level).

impact of any macro policy can be evaluated in a more balanced way involving aggregate growth, financial stability, and income inequality. ${ }^{16}$ In this context,

\footnotetext{
${ }^{16}$ In a report by the Commission on the Measurement of Economic Performance and Social Progress, Stiglitz et al. (2010) viewed inequalities as the first crosscutting challenge for quality-of-life indicators. They argued that inequalities should be assessed comprehensively by examining differences in the quality of life-across people, groups, and generations. Michael Spence (2019), another Nobel laureate, made a forceful argument for the need to pay attention on inequality issue: "Markets are mechanisms of social choice, in which dollars effectively equal votes; those with more purchasing power thus
} 
one may try to integrate a mechanism whereby a levy is imposed as a lever to dampen growth of the dangerous (short-term) component of capital flows. ${ }^{17}$ It has been shown that imposing levy could produce those three goals in a more balanced way. While the policy may be interpreted as relaxing one of the trinity, the main rationale is not to impose capital control but to reduce the risks caused by volatile short-term flows. ${ }^{18}$

\section{Closing Remarks}

Mainstream macroeconomics was unprepared to understand the roots, mechanisms and policy solutions to an event like GFC, and unable to explain why small shocks can have very large effects that last so long. Among others, this is because its core model considers the role of financial sector and its interactions with-and effects on-real sector unimportant, let alone the amplified effects and contagion of financial shocks. Yet, these effects have a very significant bearing on economic growth and business cycles, which in turn influence back the financial sector. Such complex chains of events reinforce themselves through a feedback loop, generating multiple equilibria including a bad one (crisis) in such a way that the bad equilibrium could be self-reinforcing, making it persistent and long-lasting.

This is obviously in contrast with the existing core model we teach in colleges and universities, where we describe that an economy can go off the equilibrium now and then, but any deviations could and would be corrected by inherent mechanisms in the model. On financial sector, the core model's intellectual underpinning is the 'Efficient Market Hypothesis,' where financial market is efficient, and agents know the risks and will protect themselves from such risks.

Yet, these are only fantasy. Pretension and fantasy are not far away from one another. Macroeconomists must face up to the inconvenient reality that financial frictions are a fact of life, and that financial markets fall far short of perfection subject to uncertainty and obscurity. Alas, instability in finance is a rule, not an exception.

Corrections and adjustments to existing core macroeconomic model are clearly needed. The model should not be motivated by internal logic and esthetic riddles

have more influence over market outcomes. Governments are also social choice mechanisms, but voting power is - or is supposed to be - distributed equally, regardless of wealth. Political equality should act as a counterweight to the weighted "voting" power in the market...... But governments around the world are failing to fulfill these responsibilities."

${ }^{17}$ After decades of promoting unrestricted capital flows, the IMF has finally acknowledged the merit some controls of this sort (Ostry et al., 2012; Ghosh et al., 2016).

${ }^{18}$ See Azis (2018). Note that some countries have implemented the policy. For example, in response to massive capital inflows following the QE policy, the Korean government began to impose levy on short-term inflows especially those going through the banking system. The impact of the policy was considered a success because total inflows did not fall but the composition changed towards a much lower share of short-term component. Moreover, capital flows into Korea have become less sensitive to global supply-push factors (Bruno and Shin, 2014). 
of established paradigm. Instead, it must be based on (1) a powerful desire to understand how the economy works; and (2) a common sense informed by empirical evidence and historical experience. There may not be a perfect new core model in the end. I also doubt that there should be one methodological approach to use. Embracing diversity of methodological approaches makes more sense.

Notwithstanding the imperfections, an attempt to improve our understanding is not a foolish exercise. On the contrary, it is indispensable.

\section{References}

[1] Adrian, T., \& Shin, H. S. (2009). Money, liquidity, and monetary policy. American Economic Review, 99(2), 600-605. doi: 10.1257/aer.99.2.600.

[2] Azis, I. J. (2008). Indonesia's slow recovery after meltdown. Asian Economic Papers, 7(1), 79-103. doi: https://doi.org/10.1162/asep.2008.7.1.79.

[3] Azis, I. J. (2010). Predicting a recovery date from the economic crisis of 2008. Socio-Economic Planning Sciences, 44(3), 122-129. doi: https://doi.org/10.1016/j.seps.2010.03.003.

[4] Azis, I. J. (2014). The capital market in the context of financial safety nets. In Asian Development Bank, Asian Capital Market Development and Integration: Challenges and Opportunities, pp. 31-60. Oxford University Press. https://www.adb.org/publications/ asian-capital-market-development-and-integration-challenges-andopportunities.

[5] Azis, I. J. (2015). Integration, contagion, and income distribution. In Nijkamp, P., Rose, A., \& Kourtit, K. (Eds.), Regional Science Matters: Studies Dedicated to Walter Isard (pp. 131-161). Springer, Cham. doi: https://doi.org/10.1007/978-3-319-07305-79.

[6] Azis, I. (2018). Coping with the dangerous component of capital flows and Asia's ineffective cooperation. In Pixley, J. \& Flam, H. (Eds.), Critical junctures in mobile capital (pp. 52-67). Cambridge University Press.

[7] Azis, I. J., \& Shin, H. S. (2015). Managing elevated risk: Global liquidity, capital flows, and macroprudential policy-An Asian perspective. Springer Singapore.

[8] Azis, I. J., Mitra, S., \& Baluga, A. (2013). Global shock and regional spillovers. Peace Economics, Peace Science and Public Policy, 19(2), 183-211. doi: https://doi.org/10.1515/peps-2013-0014.

[9] Bernanke, B., \& Gertler, M. (1989). Agency costs, net worth, and business fluctuations. The American Economic Review, 79(1), 14-31.

[10] Bernanke, B., Gertler, M., \& Gilchrist, S. (1996). The financial accelerator and the flight to quality. The Review of Economics and Statistics, 78(1), 1-15. doi:10.2307/2109844

[11] Blanchard, O. (2016). Do DSGE models have a future? Policy Brief 16-11. Peterson Institute for International Economics. Washington D.C. https://www.piie.com/ publications/policy-briefs/do-dsge-models-have-future.

[12] Blanchard, O. (2017). Macroeconomics (7th edition). Pearson.

[13] Bourguignon, F. (2004). The poverty-growth-inequality triangle. Working Paper No. 125. Indian Council for Research on International Economic Relations (ICRIER). New Delhi. http://www.icrier.org/pdf/wp125.pdf.

[14] Bruno, V., \& Shin, H. S. (2012). Capital Flows and the Risk-Taking Channel of 
Monetary Policy. BIS Working Papers, No 400. Bank for International Settlements. https://www.bis.org/publ/work400.pdf.

[15] Clark, J., Converse, N., Coulibaly, B., \& Kamin, S. B. (2016, October). Emerging market capital flows and U.S. monetary policy. IFDP Notes. Washington: Board of Governors of the Federal Reserve System. doi: https:/ / doi.org/10.17016/2573-2129.23.

[16] Engle, R. F., \& Kroner, K. F. (1995). Multivariate simultaneous generalized ARCH. Econometric Theory, 11(1), 122-150. doi: https://doi.org/10.1017/S0266466600009063.

[17] Feenstra, R. C. \& Taylor, A. M. (2014). Essentials of international economics (3rd edition). New York, NY: Worth.

[18] Friedman, M. (1968). The role of monetary policy. American Economic Review, 58(1), $1-17$.

[19] Gertler, M., \& Kiyotaki, N. (2010). Financial intermediation and credit policy in business cycle analysis. In B. M. Friedman \& M. Woodford, Handbook of monetary economics (Vol. 3, pp. 547-599). Elsevier. doi: https:/ /doi.org/10.1016/B978-0-44453238-1.00011-9.

[20] Ghosh, A. R., Ostry, J. D., \& Qureshi, M. S. (2016). When do capital inflow surges end in tears?. American Economic Review, 106(5), 581-85. doi: 10.1257/aer.p20161015.

[21] Hicks, J. R. (1937). Mr. Keynes and the" classics"; a suggested interpretation. Econometrica: Journal of the Econometric Society, 5(2), 147-159. doi: 10.2307/1907242.

[22] Kiyotaki, N., \& Moore, J. (1997). Credit cycles. Journal of Political Economy, 105(2), 211-248. doi: https://doi.org/10.1086/262072.

[23] Krugman, P. R., Obstfeld, M. \& Melitz, M. J. (2015). International economics: Theory and policy (10th edition). Boston, MA: Pearson.

[24] Ostry, M. J. D., Ghosh, M. A. R., \& Korinek, M. A. (2012). Multilateral aspects of managing the capital account. IMF Staff Discussion Note, SDN/12/10. International Monetary Fund. https://www.imf.org/external/pubs/ft/sdn/2012/sdn1210.pdf.

[25] Prescott, E. C. (1986). Theory ahead of business-cycle measurement. Carnegie-Rochester Conference Series on Public Policy, 25, 11-44. doi: https://doi.org/10.1016/0167-2231(86)90035-7.

[26] Samuelson, P. (1951). Principles and rules in modern fiscal policy: a neoclassical reformulation. In H. L. Waitzman (ed.), Money, trade and economic growth: Essays in honor of John Henry Williams. New York, Macmillan.

[27] Stiglitz, J. E. (2001, December 8). Information and the change in the paradigm in economics. Prize Lecture. The Nobel Foundation. https:/ /www.nobelprize.org/prizes/ economic-sciences/2001/stiglitz/lecture/.

[28] Stiglitz, J. E. (2014). Reconstructing macroeconomic theory to manage economic policy. NBER Working Paper No. 20517. National Bureau of Economic Research. https: //www.nber.org/papers/w20517.

[29] Stiglitz, J., \& Greenwald, B. (2003). Towards a new paradigm in monetary economics. Cambridge University Press.

[30] Stiglitz, J. E., \& Greenwald, B. C. (2014). Creating a learning society: A new approach to growth, development, and social progress. Columbia University Press.

[31] Stiglitz, J. E., Sen, A., \& Fitoussi, J. P. (2010). Mismeasuring our lives: Why GDP doesn't add up: The Report by the Commission on the Measurement of Economic Performance and Social Progress. The New Press.

[32] Stiglitz, J. E., \& Greenwald, B. (2004). Rumo a um novo paradigma em economia monetária. Francis.

[33] Shiller, R. J. (2015, January 16). What good are economists? World Economic Forum. 
https://www.weforum.org/agenda/2015/01/what-good-are-economists/.

[34] Spence, M. (2019, August 1). The inequality of nations. Project Syndicate. $\quad$ https://www.project-syndicate.org/commentary/ market-power-encroaching-on-politics-by-michael-spence-2019-08.

[35] McKay, A., \& Thorbecke, E. (Eds.). (2015). Economic growth and poverty reduction in sub-Saharan Africa: current and emerging issues. Oxford University Press.

[36] Vines, D., \& Wills, S. (2018). The rebuilding macroeconomic theory project: an analytical assessment. Oxford Review of Economic Policy, 34(1-2), 1-42. doi: https://doi.org/10.1093/oxrep/grx062. 